\title{
Study of Policy Formulation in Drafting Regional Regulation Number 3 of 2017 concerning Riau Malay Customary Institutions, Dumai City
}

\author{
Ahmad Tarmizi $^{1}$, Nurfitriana ${ }^{2}$, Moris Adidi Yogia $^{3}$, Teuku Afrizal ${ }^{4}$, Ari Subowo ${ }^{5}$ \\ ${ }_{1,2,3}$ Universitas Islam Riau, Indonesia \\ ${ }^{4,5}$ Faculty of Social and Political Sciences, Universitas Diponegoro, Indonesia \\ tarmiziuir@soc.uir.ac.id,fitrigafar79@gmail.com,moris.adidiy@soc.uir.ac.id, \\ *teukurian@lecturer.undip.ac.id
}

\section{Abstract}

This research focuses on the Formulation of Regional Regulation Policy Number 3 of 2017 concerning the Riau Malay Customary Institution, Dumai City. This study aims to examine the process of formulating a Perda policy by the Dumai City DPRD and related institutions. This study used a descriptive qualitative approach, in which the informants were determined by purposive sampling from various related agencies. The results of the study found that the process of determining Perda policies follows the direction of the prevailing laws, but the compilation process has not been carried out in a holistic manner, it is lacking in depth, especially in the phase of setting the policy agenda. In this context, it was found that the identification of the problem was not very deep related to the problems and peculiarities of the local cultural, customary and historical conditions. Apart from the Perda, there is also no clear framework for protecting, defending and fighting for the fate of indigenous peoples and local communities. Furthermore, in the drafting phase, it has not yet mobilized public participation, including providing public space and public discussions. In fact, this shows the openness in the formulation phase of the Perda. The interesting thing here is that the concept of the Perda in broad terms refers too much to the Perda of the Riau Provincial Malay Customary Institution. So it is advisable to clarify the concept and frame work "so that it is affective in achieving the mission and goals of the Riau Malay Customary Institution. This study concludes that the Perda is more oriented towards micro interests, namely internal organizations, besides the need to have a legal basis, it can also be used as a basis for obtaining grant allocation from the Dumai City APBD.

\section{Keywords}

policy formulation; Riau malay customary institution perda; sustainable development goals

\section{Introduction}

As a large local mass organization, the existence of the LAMR (Riau Malay Customary Institution) is very important in; (i) fostering, choosing, developing and passing on the noble values of the Riau Malay Customs and Culture; (ii) realizing an advanced, just and prosperous indigenous community with a civil society structure; (iii) defend and fight for the rights of indigenous peoples to improve physical and spiritual welfare (Article 4). So the process of developing culture and customs in Riau's increasingly open conditions has made a field for exploitation and exploration of natural resources extraordinary. So it is not uncommon to make indigenous groups more marginalized and slowly also get rid of these communities. 
In fact, the important mission of LAMR is to defend and fight for the rights of indigenous peoples. This means that the external mission carried out by AMR is heavier than the internal mission. Their struggles and hard work related to the expansion of the capitalist economy have disturbed the existence of the natural life of indigenous communities, their environmental resources have become extinct, which has led them to be displaced from their own hometowns. So it is impossible for culture and traditional customs to live and develop without "space" layout such as forest / land / land which is no longer natural and safe and even threatens the existence of customs and local wisdom of future generations. Many of the various cases of the economic expansion process did not respect the rights of indigenous peoples who unwittingly negated their nature ecologically, especially in context. factual human environment "human ecology" is related to "mutual relations, collectivity, between organisms their environment. Non-ecological interests that tend to "ride" the ecological agenda can become a threat. (Ismawan, 1999: 138)

The fact is that the existence of LAMR in the City of Dumai is increasingly convinced and established with the enactment of the Dumai City Regional Regulation Number 3 of 2017 concerning the Riau Malay Customary Institution, Dumai City. Ideally the Perda provides more space in the context of continuing the existence of LAMR Dumai to develop the organization. Among them are things that are important for the establishment of an organization that requires financial support. That is why with the regional regulations, organizations are more legitimate to get donations from the APBD. Even so, the enactment of this Perda has a relatively long grace period compared to the Provincial LAMR Perda which was enacted in 2012.

The legislative process to stipulate the LAMR DUMAI Perda took one year during 2016. Ideally, the public policy process is reviewed in the initial phase, namely formulating a policy "policy formulation" aimed at solving problems and making conditions better, able to elevate the dignity of indigenous peoples. References referred to in making the policy agenda "policy agenda" should be based on the real life reality of local indigenous peoples who are "localited". When indigenous peoples still experience social, economic and humanitarian problems from the undermining of rapid economic expansion. Among them in Dumai, the condition of the rights of the indigenous Sakai tribal people was neglected by the expansion of oil mining and its sustainability needs to be considered. The policy agenda in the context of problem identification should be formulated in the setting and reality of the "indigenous peoples'" problem. This is in accordance with the aim of formulating public policy "the expected result of policy formulation is some type of solution to a problem" (Lester and Stewart, 2000: 87). Meanwhile, the existence of the LAMR organization is increasingly needed as an organization that can develop the conditions of indigenous peoples in the current era, as stated by Bennis (1994: 223) that the organization is the main form of community progress that should appear as a social architect. The government apparatus and social architects must redesign their organization along more human and functional lines (Bennis, 1994: 42).

Policy formulation is a systemic and comprehensive process and is not otherwise narrowly oriented, and not from a utility point of view. So far, instantaneous thinking has been micro-oriented, how can customary institutions exist which should develop and be able to realize and develop the main mission of the policy objectives themselves. Preserving, defending and fighting for the rights of indigenous peoples. One important question is "what will LAMR do after the policy is set". Whether the role of LAMR can be increased and its existence recognized in the aspect of the sustainability of the lives of indigenous peoples or local indigenous people. So far, people who seem weak in facing challenges and the tendency to conflict of interest have also eroded the purity of the spirit 
of struggle. According to Guido and Alan (2007) sustainable development in the development process: 'the developments in the social arena have also been remarkable, and. according to him again, "the achievement of any set of policy goals, and especially any as ambitious as the Millennium Development Goals, requires more than just good public policy. For Riau's experience, when natural resources, especially forests, are cleared carelessly, then sustainable development is only a necessity and is threatened. (Tarmizi, 2017: 211) by Zainal, it is said that all Malay people are indeed dealing with uncertainties in facing the reality of life which is increasingly tense due to the progress of the times (Zainal, 2006: 12). Society is a collection of people who live together for quite a long time (Corry et al, 2020). In conditions of transitional society like this, especially in traditional conditions and $\mathrm{h}$ Wilson is said to need to take a delicate approach to Wilson's "delicate machinery" (Tarmizi, 2017: 209)

Especially in the context of Indonesia, now the process of achieving the sustainable development of a new public administration, namely realizing social justice and social equality, upholding human rights, resolving the problem of poverty, "poverty" embodies the spirit of partnership and partnership "partnership". Since the existence of indigenous peoples is important in maintaining and protecting the preservation of nature, naturally we all always pay more attention to indigenous peoples. Experience in handling land and land cases for indigenous peoples in Riau, although in the era of regional autonomy the role of the government has not been significant in resolving land and forest-land disputes or facilitating public and private interests, namely "forest entrepreneurs. Public administration with a cooperative spirit and persuasive communication with its official authorities can create a climate that is not conducive to harmony. (Tarmizi, Surya and Romayani, 2018) In this case, sometimes LAMR appears to help the interests of indigenous peoples.

Regrettably, the Perda does not provide a clear framework for this. In the event that until today there are still many cases of returning the rights of indigenous peoples that are still being denied. When the position of the indigenous people is getting squashed and it is difficult, it seems that their struggle seems endless. Even their human rights are challenged and most of them are physicist and "static". So, this version should have a well-structured regional regulation having a fighting spirit, power because the Perda regulation becomes a reference for LAMR to work and fight for the rights of indigenous peoples as expected.

\section{Review of Literature}

Public policy is "what the government chooses to do or not do (Dye, 1978). According to Birkland,: "Policy is generally made or initiated by government (Birkland, 2016). Meanwhile, Heclo argues that the government process is outlined in real and legitimate guidelines in the name of the public interest. It means that public policy becomes a real guideline in running the government. According to Anderson also, that public policies are policies developed by government agencies and their apparatus (Anderson, 1989). PBB makes a policy concept consisting of, "law, planning, regulation, decision making, action and behavior. Heclo in Candace 2013: 1267) argues: "views the relationship between policy and administration as a vital relationship. Specifically, according to Ham and Hill (1985) a study of public policy processes "are often concerned with single issues of this kind or with specific policy area. Look at a process policy process that concentrates on a single issue that really does well and on a specific area. Among the choice of policies, a place is capable of determining policy problems that are truly in accordance with the needs of the situation. Easton said that the policy choices were not made carelessly or haphazardly (Easton, 1979). 
The existence of an organization is closely related to policy. However, organizational involvement cannot be avoided in the success of a policy. Likewise, the policy itself is made through the organizational process, the goals are held by the organization and the final accountability remains through the organizational process. In this case the Perda is not only aimed at LAMR, but more importantly whether the LAMR organization is capable of working and whether the policy can be used as a clear and strong guideline for LAMR to carry out the main mission of the policy, of course $i$ has gone through policy references clear, as well as whether this organization has a real capacity in administering the Regional Regulation to be drafted, or is this Perda determined to have other intangible or implied interests even though it is counterproductive and the initial objective of establishing the Perda itself. Because many policy problems do not have to be resolved by the government. (Nigro and Nigro, (2012: 30). The tightness of public policy with the organization in detail is stated by Hall and Quin. (1) Organizations are the mean by which public policy is implemented. (2) public policy is formulated organization settings. (3) public policy is formulated government agencies. (4) Organizations are the object public policy.

For the experience in Indonesia, sometimes in many ways related to policies and controversial matters with the mission of the organization as stated by Topimasang that: "Many organizations aspire to fight for social justice, but given the complexity, breadth of dimensions and aspects of social injustice. ... So many organizations are trapped as "social craftsmen", and even then are unable to get out of the trap. (Topimasang, 2005: x)

Public policy formulation is "solutions to those problems, and assessing the impact of those solutions on the target problem (Leon) in (Smith and Larimer) Then Cochran and Malone (1996), state that policy formulation is an effort carried out with the aim of addressing problems, and priority goals. According to Lester and Stewart, the process of formulating public policy through inducement steps and characteristics; ruler; fact; right and power (Lester and Stewart, 2000,87). According to Ripley and Franklin (1976) the formulation of determining policy decisions consists of four principles (1) at least important positions in various issue areas. (2) great variety of governmental institutions (3) Share power... basic government function, (4) tremendous variety and volume of issues facing government. (Ripley and Franklin, 1976).

According to Meyer and Ernest, the steps to formulate the policy consist of (1) Determination of Goals (2) Need assessment (3) Specification of objectives (4) Design of alternative courses of action (5) Estimation of the consequences of alternative action (6) Selection of the course(s) of action (7) Implementation of the action(s) (8) Evaluation outcomes (modification of goals, objectives, and courses of action based on feed back. (Meyer and Ernest, 1980: 8)

Therefore, legislation is made as ideal as possible where planning as the initial step of formulation is the same between the steps of identifying problems and sorting other problems into research problems, not only set in an academic paper, it is also important in a comprehensive analysis. According to Dunn regarding the policy problem "policy problem" is the value, need and opportunity that has not been fulfilled but can be identified and achieved to take public policy action "public policy action". (Dunn, 1988: 92). Formation of Legislation includes the stages of planning, preparation, discussion, ratification or stipulation, and promulgation. " Article (1) Law Number 12 Year 2011) the following steps (1) Clarity of purpose; (2) Institutional or appropriate forming officials; (3) Conformity between types, hierarchies, and cargo material; (4) Can be implemented; (5) efficiency and efficiency; (6) Clarity of formulation; and Openness (article 5. Law Number 12 Year 2011) 
From a public management approach, policy making must empower communities, not just provide services. In a review of the reinvention aspect, the government has a role to reorganize. (Parsons, 2008: 461) Among the characteristics of good policy, according to Caiden, it requires a framework and a concept that is good and correct and also really requires community participation (Caiden, in Thoha, 2011)

In the process of implementing policies, even if the government has limited resources, it must show its capacity. Because it has three human resources, power and authority (Wilson, 1887), this is a challenge for the government as it says that: "administration is the management of affairs. It is concerned with the implementation of public policy laid down by men in power and authority "he said again that administration has an important role" Policy does nothing without the aid of administration. Especially if the policy itself has the support and participation of the community. It was said by Frederickson, that, decision processes accompanied by open and full participation have long been the principles of good management practice. (Frederickson, 1989: 19)

In terms of fighting for the fate of indigenous peoples, both the government and LAMR, through clear commitment and alignments with the "indigenous communities", there are many ways that can be realized as long as they are consistent. In this case, LAMR's position is in line with its aim of being able to strengthen the power of the public "through the process of strengthening and restructuring the organization" reengineering organizations "can partner with the government in helping solve problems experienced by indigenous peoples. The results of the observations of the researcher's study in the provincial LAMR that in an average of one month there were 3 to 4 cases that were complained by the indigenous community for help in resolving them. Most of the complaints submitted relate to cases of land forest conflict, namely community land that was seized by entrepreneurs. The impacts of forest exploitation on rural communities are complex. (Marzali, 2012: 131) The process of forming the LAMR Perda policy should consider the urgency of this factor. An understanding of the conditions being faced by indigenous peoples, most of whom live in forests and underdeveloped villages, are scattered in remote areas with various problems. Legal recognition and protection for indigenous peoples is very necessary to avoid the lives of indigenous peoples so as not to be increasingly discriminated against and marginalized, but also in accordance with national law as well as international law and human rights (Wahiduddin: 2013) Experience in Riau, where most of the indigenous peoples are in a weak community position and are always crushed by the political and economic problems of the games of businessmen with power cunning.

The indigenous Malay people of Petalangan are still struggling to restore their Ulayat lands in Pelalawan. They are weak and fall when dealing with large investors and finally eliminated from the customary life of the "forest-land hometown since their ancestors became the source of their life as" virgin "Now they have no place anymore because their forest land has turned into a coconut plantation. palm oil started from the New Order era. Much of their local wisdom, products of their culture and customs, were also destroyed at the same time they were exiled from their hometowns. Whereas traditional environmental management as ancestral customs and wisdom of the Petalangan people is very unique and interesting to study and continue, especially in the context of sustainable development. (Tarmizi and Kurniawan, 2017). Then viewed from the historical aspect, the Petalangan Malay community has a wealth of natural resources "Tanah Kayat", namely Land Forests which are properly administered to belong to the tribal community or Pesukuan. 2010). Amazingly, based on experience in Riau, even though the era of regional autonomy has exceeded two decades, the role of the government of "public administration" has not 
significantly changed policies that are not pro-people and have not been able to harmonize public life with business. In fact, what is prominent and dominant is the "capitalist economic interest". This means that in relation to forests and land and ownership of indigenous peoples, there is almost no change in policy "policy change" which favors the interests of indigenous peoples. (Tarmizi, Romayani and Suryani)

\section{Research Methods}

This research is a descriptive qualitative research. This research process includes fact finding, Hiilway's critical interpretation in Mukhtar (2012: 13). more emphasis on social life "more areas of social life" Neuman (2006: 157) also relates to experiences and events in the human environment. According to Twumasi it is saidIt aims to objectivity in its effort the gather meaningful knowledge from the empirical world(Twumasi, 1986). Build a complex and holistic picture of certain phenomena using natural settings. (Jecik, 2013: 826) A.D.describing existing phenomena, which take place at this time or in the past, (Lexy: 2011: 14). In contextpublic administration contributes to political life "political life (Wilson, 1887) Judging from the way it works at the surface level (appearance) and also below the surface. Both ways can be done (Straus and Corbin, 2003: 4-6); In the context of research, policy formulation, as according to Lester and Stewart, makes the type of policy research, including the test frame work model (Lester and Stewart, 2000: 80). Key informants are part of the government and not the government, such as part of the DRPD legislation as key informants, key informants: other sources, local government lawyers, LAMR administrators and customary community leaders. Obtaining information to the resource person is carried out through an in-depth interview process, both direct and indirect, structured and unstructured (free interviews) and also sourced from documentaries, both from files, source of literature reading is done "literature review. In addition to the above method, content analysis is also carried out through content analysis "Contents Analysis". Submission and presentation of the results of the analysis "research results display" is conveyed descriptively, prescriptively or comparisons and then conclusions are drawn.

\section{Results and Discussion}

The process of establishing the Dumai City LAMR Perda has referred to the official rules in force, namely Law Number 12 of 2011 concerning the Formation of Legislative Regulations and in addition to referring to the Regulation of the Minister of Home Affairs of the Republic of Indonesia Number 80 of 2015 concerning the Formation of Regional Legal Products. The first time it begins with forming a team and gathering relevant information including the relevant rules and regulations. Because in theory, the policy nature of the rules does not stand alone and complement each other for the perfection of policy products. Among them, the planning process prepares various materials in the form of relevant information including preparing academic papers as facts for assessment and alignment of subsequent activities. Second, is the stage of Formulating City Regional Regulations, carried out in coordination with the Provincial LAMR, by the legal bureau and involve relevant agencies both at the city and provincial levels including the provincial LAMR and other stakeholders. Third, the discussion of the Draft Regulation is carried out jointly through the discussion process at the city levels and also at the meeting arrangements of the DPRD commissions / committees / bodies / organs that specifically handle the field of legislation and through plenary meetings which have been coordinated 
with the legal department of the Dumai Mayor's Office. Fourth, is the stage of the Determination of the Draft City Regional Regulation, the process of submitting the Draft Regional Regulation is carried out within a maximum period of 7 (seven) days from the date of mutual agreement. The signing process is carried out within a maximum period of 30 (thirty) days from the Dumai City Regional Regulation Draft and is jointly approved by the Dumai City DPRD.

The process of establishing the Dumai LAMR Regional Regulation reflects the continual policy of the nature of the partnership between the DPRD "legislative" and "executive" local governments, complementing each other between the two parties. Ideally, this practice aims to make the policy products it produces are of higher quality which later can be used as a frame of reference in implementing the "policy execution" policy, which is mainly carried out by LAMR in Dumai City. Even though post-determination of the policy has not shown significant results (outcome), however, for LAMR Dumai City the Perda is useful as a legal umbrella "legality principle" to obtain grant assistance from the Dumai City APBD, although in a relatively small amount when compared to activities and problems experienced by LAMR in the city of Dumai.

Ideally, the process of formulating public policies through inducement steps and characteristics; ruler; fact; right and power (Lester and Stewart, 2000: 87). At the inducement stage, the breastfeeding process is more urgent in terms of the target problems that are considered important to raise the issue and discuss intensely. In this case the driving factor is more focused on the interests of the LAMR organization rather than the objectives and mission of LAMR. One of the most dominant driving factors is that LAMR has a strong legal basis and can legally obtain a grant allocation from the Dumai city government budget. Then with regard to the role of "ruler" which should not only be about the role of institutions that have "government" authority in the process of determining policies. However, it needs to be prepared when a Perda is stipulated through a policy that has a solid "frame work" framework to instruct the implementing agencies with detailed completeness that can be used as an excellent reference in order to achieve targets in accordance with the mission and objectives of LAMR. Because public policy is not only related to decisions (decisions) but also implementation or action (action). However, the public policy process will one day be a questionable and criticized issue. As Laswell said, "ho gets whats, when and how" "who gets what when and how". That is precisely why a critical analysis of the policy itself demands that the process of formulating policies needs to be carried out carefully and carefully so that their existence and role throughout the policy process can be accounted for. The next step is to reveal the fact "Fact" is also very important in relation to the process of identifying problems being faced by the subject and policy object should go through a comprehensive and in-depth process, among which unique, specific and factual facts become important considerations. In the process of determining the policy agenda, the "policy agenda" facts and problems in society are important issues to be discussed and on the agenda. Therefore, contextual and factual differences with regard to customs and culture should be considered in identifying agenda issues and formulating policies. The reality in the research on the contens analysis in outline of the Dumai City LAMR Perda refers to the concept of the Riau Province LAMR Perda.

Among them are the first steps in identifying the problem of the demands of the indigenous Sakai Dumai tribe who are marginalized by foreign mining companies such as CPI that have not been included on the agenda. In fact, they have long been eliminated if their land and forest of life are used for capitalist economic expansion. Batin Mansur, as the leader of the indigenous Sakai tribe, is still fighting for Sakai's ulayat lands. The 
position of the Sakai people is threatened in their own country. Recently a resident of Sakai in Duri 13 was convicted of planting sweet potatoes in a forest clamped in the company's HGU area. Regrettably, in the judicial process, the district or provincial LAMR did not show an attitude of defending indigenous peoples.

The next step relates to power, which uses potential and resources apart from the power and authority to formulate policies, in this case being the authority of the local government, also needs to elaborate on other strengths of the policy process supported by public potential in the process of public participation. Organizational power is no less important in placing a constructive policy framework as an important guide in taking action to increase the dignity and dignity of indigenous peoples. There is a possibility that there is a power that has not been raised to raise local customs, such as exploring the historical aspects of the Bungo Tanjung kingdom, the Tomb of Putri Tujuh, the legend of Bangsal Aceh and the Dumai River as well as several place names that have cultural and historical values. Including the culture of the Sakai people in preserving the environment and managing the sialang forest as a habitat for bees. The point is, from the cultural aspect of customs, with the establishment of a partnership between LAMR and the government, many good things can be done. Where is the task of the government in implementing policies as stated by Wilson (1887) "administration is the management of affairs. It is concerned with the implementation of public policy laid down by men in power and authority.

Finally, there is a very important issue regarding the issue of "right" rights which needs to be an important concern in determining public policy. Because this problem empirically becomes the main problem for restoring the human rights of indigenous peoples in the economic arena in Riau for the sake of public interest. The current reality of the condition of the oppressed indigenous people has started from the events of the New Order which to this day have not been completed and remains an important issue. Regrettably, this issue is not one of the problem identification steps in setting the LAMR Dumai local regulation policy agenda. In fact, in general, many of them have been displaced from their hometowns and have turned into business areas that can no longer be impressed with the naked eye. In fact, many historic villages and old villages along with the customs of their local people have been lost along with the cultural anthropology of the past. Meanwhile, the physical evidence along with forest clearing in Riau, as wide as the eye can see, has turned into a homogeneous forest. Reviewing making specific regional policies regarding indigenous peoples is in line with the main objectives and mission, preserving, developing, defending and fighting for the rights of indigenous peoples and culture should take important issues and problems of human rights so that they are not separated from the context of the existence of the LAMR that was born and formed boils down to indigenous peoples.

Student satisfaction in this study has significant influence to student loyalty. The results of the study are in line with (Ramadhani, 2017) which implies that giving intrinsic rewards can increase student loyalty through student satisfaction. Thus, the management and foundations at higher education institutions must have a strong commitment to give rewards, especially to students who are able to recommend studying at their campus. 


\section{Conclusion}

The results of the study found that in general, the process of establishing policies. The decision of the Dumai City LAMR Perda has gone through a procedure that has followed the procedure as outlined in the laws and other government regulations. However, the process of setting the agenda, especially in identifying it, is still not holistic, especially with regard to cultural realities and problems currently being faced by indigenous peoples and local communities. Mak, it is recommended that the agenda setting, which is an important discussion, leads to conditional and contextual matters according to the local specifics "locallited." The goal is that the problems faced by indigenous peoples and local communities in Dumai can become an agenda for policy issues and are clearly outlined in the Perda to be followed up and part of LAMR's dedication in defending and fighting for the rights of indigenous peoples and local communities. Likewise, in order to further strengthen LAMR's performance management in the future, there are more detailed rules to serve as guidelines for developing the organization as well as to serve as a reference for LAMR's moral guidelines and code of ethics. For the sake of sustainability of LAMR together with its environmental system, rules or policies are made that are oriented towards achieving the goals of sustainable development (Sustainable Development Goals). The suggestion is to modify more comprehensive policies, because the LAMR organization is expected to carry out heavier missions, tasks and responsibilities in the future in facing the demands and environmental pressures of the city of Dumai as a city of international Industry and Trade which continues to grow rapidly.

\section{References}

Abdul Wahab. Solihin. 2005. Analisis Kebijaksanaan Publik Dari Formulasi ke Implementasi Kebijaksanaan Negara. Bumi Aksara. Jakarta.

Bennis, Warren dan Mische Michael. 1995. Organisasi Abad 21 Reinventing melalui Reeginering.(terj) Irma Indriani Rachmayanti. Pustaka Binaan Pressindo. Jakarta.

Bertucci Guido dan Rosenbaum Allan. 2007. Implementing the Millennium Development Goals: Challenges and Responses for Public Administration. United Nations New York, 2007

Corry, et al. (2020). Cultural Meaning of Monument Buildingin the Life of Toba Batak Tribe in Pangururan and Palipi Subdistricts, Samosir Regency. Britain International of Humanities and Social Sciences (BIoHS), Vol. 2, No. 2, Page: 392-402.

Dye R.Thomas. (1972 ). Understanding Public Policy, New Jersey : Prentice Hall Inc Englewood Cliffs.

Dunn A. William. 1988. Analisa Kebijaksanaan Publik. Hanindita. Yogyakarta

Easton, David. (1979). A frame Work for Political Analysis. Chicago : The University of Chicago Press

Effendy. Tenas 2010. Kearifan Pemikiran Melayu. Yayasan Tenas Effendy. Pekanbaru

Frederickson H, George. 1989. Administrasi Negara Baru (terj) Al- Ghozei Usman. LPS 3 ES. Jakarta.

Ismawan Indra . 1999. Resiko Ekologi di balik Pertumbuhan Ekonomi. Yayasan Adikarya IKAPI dan The Ford Fondation. Yogyakarta.

Jencik Alicia. 2013. Riset Kualitatif Versus Kuantitatif. (ed) John T. Ishiyama dan Marejke Breuning "Ilmu Politik dalam Paradigma Abad 21 Sebuah Referensi Panduan Tematis. (terj) Tri Wibowo. Prenada Media Group. Jakarta 
Lester P. James dan Stewart. Joseph Jr. 2000. Public Policy An Evolutionary Approach. Second Edition. Wadsworth Thomson Learning. Belmont USA.

Marzali, Amri 2012. Antropolgi dan Kebijakan Publik. Kencana Prenada Media Group. Jakarta.

Meyer R. Robert dan Greenwood. Ernest 1980. The Design of Social Policy Reseach. Printice Hall. London

Mukhtar. 2012. Metode Penelitian Deskriptif Kualitatif. Referensi. Jakarta.

Neuman W. Laurence. 2006. Social Research Methods, Qualitative and Quantative Apparoaches. Pearson. Boston.

Nigro A. Fellix dan Nigro L, Llyod. 2012. Administrasi Publik Modern (terj) Yudi Santoso. PalMall. Yogyakarta.

Parsons. Wayne Parsons. Public Policy "Pengantar Teori dan Praktik Analisis Kebijakan. (terj) Triwobowo Budi Santoso. Kencana Prenada Media. Jakarta.

Randall B. Ripley and Crace A. Franklin. 1976. Congress, the Bureaucracy and Public Policy. Dorsey Press. Homewood Illinois.

Smith B. Kevin B and Larimer W. Christopher . 2009. The Public Policy Theory Primer . 2009 by Westview Press Phi ladelphia

Strauss Anselm dan Corbin Juliet. 2003. Dasar-dasar Penelitian Kualitatif. (terj) Mohammad Shodiq dan Imam Muttaqien. Pustaka Pelajar. Yogyakarta.

Tarmizi Ahmad. The role public administration in strengthening the Capabilities of Organization of Regional Autonomic Era Governen. Prociding International Seminar Strengthening Bureaucratic Capacity of Public Administration in the Context Local Instituion. August, 2017. Public Administration Program UR Pekanbaru and IAPA The Midle of Sumatra Region.

Tarmizi Ahmad Tdan Kurniawan Andri. Model Administrasi Pribumi Masyarakat Melayu Petalangan Di Desa Sialang Godang Kabupaten Pelalawan Riau. Prosiding Mitigasi dan Stategi Adaptasi Dampak Perubahan Iklim di Indonesia . Prosiding Seminar Nasional UIR 2017. Pekanbaru, 24-25 Februari 2017.

Tarmizi Ahmad, Suryani Lilis, Rosmayani. . Harmonisasi Administrasi Publik dan Bisnis, Meningkatkan Peranan Administrasi Dalam Pemanfaatan Hutan dan Lahan Mewujudkan Tujuan Pembangunan Berkalanjutan " Pengalaman di Riau” Proceding Seminar Nasional Bussiness- Government an Public. Optimalisasi Governansi Bussiness Partnership (GBPs). Unpar Bandung 28 November 2018

Thoha. Miftah 2011. Administrasi Publik Kontemporer. Kencana Prada Media Group. Jakarata.

Topimasang. Roem; Fakih Mansoer; dan Rahardjo Toto. 2005. Mengubah kebijaksanaan public. Insist Press. Yogyakarta

Twumasi. P.A. 1986. Social research in Rural Communities. The Problem of Fieldwork in Ghana. Ghana Universities Press. Accra

Young C. Candace 2013. Kebijakan Publik dan Administrasi Publik. (ed) John T. Ishiyama dan Marejke Breuning "Ilmu Politik dalam Paradigma Abad 21 Sebuah Referensi Panduan Tematis. (terj) Tri Wibowo. Prenada Media Group. Jakarta

Zainal Rusli. HM. 2006. Pentingnya Kerjasana Lembaga Adat Melayu Antara Provinsi se Sumatra melalui Sekretariat Bersama" disampaikan dalam Pembukaan Musyawarah dan Seminar Lembaga Adat Melayu Sesumatra. Sambutan Gubernur Riau.

Wahiduddin Adan. 2013. Perspektif Pemerintah Atas Hak dan Kewajiban Masyarakat Hukum Adat. Lokakarya Nasion tentang Putusan Mahkamah Konstitusi Nomor 35/PU-X/2012. Jakarta 30 Agustus 2013 
Wilson. W. 1887. "The Study of Administration" (ed) Shafritz M. Jay. dan Hyde C. Albert Classics of Public Administration. Moore Publishing Company Oak Park Illinois.

Undang-Undang Republik Indonesia Nomor Nomor 11 U Pembentukan Pembentukan Peraturan Perundang-Undangan

Peraturan Menteri Dalam Negeri Republik Indonesia Nomor 80 Tahun 2015 tentang Pembentukan Produk Hukum Daerah

Pemmerintah Daerah Provinsi Riau. Peraturan Daerah Nomor 1 Tahun 2012 tentang Lembaga Adat Melayu Riau. "LAMR"

Pemerintah Daerah Kota Dumai Peraturan Daeran Nomor 3 Tahun 2017 tentang Lembaga Adat Kota Dumai Anggaran Dasar dan Anggaran Rumah Tangga Lembaga Adat Melayu Riau. "LAMR" 